\title{
Psychotropic Effects of an Alcoholic Extract from the Leaves of Albizia zygia (Leguminosae-Mimosoideae)
}

\author{
Patrick Amoateng, ${ }^{1}$ Dorcas Osei-Safo, ${ }^{2}$ Kennedy Kwami Edem Kukuia, \\ Samuel Adjei, ${ }^{3}$ Obed Awintuma Akure, ${ }^{1}$ Constance Agbemelo-Tsomafo, ${ }^{3}$ \\ Shirley Nyarko Adu-Poku, ${ }^{3}$ and Kenneth Yaw Agyeman-Badu ${ }^{3}$ \\ ${ }^{1}$ Department of Pharmacology \& Toxicology, School of Pharmacy, College of Health Sciences, University of Ghana, P.O. Box LG 43, \\ Legon, Accra, Ghana \\ ${ }^{2}$ Department of Chemistry, School of Physical and Mathematical Sciences, College of Basic and Applied Sciences, University of Ghana, \\ P.O. Box LG 56, Legon, Accra, Ghana \\ ${ }^{3}$ Department of Animal Experimentation, Noguchi Memorial Institute for Medical Research (NMIMR), College of Health Sciences, \\ University of Ghana, P.O. Box LG 581, Legon, Accra, Ghana
}

Correspondence should be addressed to Patrick Amoateng; pamoateng@ug.edu.gh

Received 30 June 2017; Accepted 13 August 2017; Published 3 October 2017

Academic Editor: José C. T. Carvalho

Copyright (C) 2017 Patrick Amoateng et al. This is an open access article distributed under the Creative Commons Attribution License, which permits unrestricted use, distribution, and reproduction in any medium, provided the original work is properly cited.

Background. Albizia zygia is used in Ghanaian traditional medicine for the management of mental disorders. The present study tested the hypothesis that an extract of the leaves of Albizia zygia (AZE) may possess antipsychotic and antidepressant properties. Method. The novelty- and apomorphine-induced locomotor and rearing behaviours of AZE in mice were explored in an openfield observational test system. The effects of AZE in apomorphine-induced cage climbing test, extract-induced catalepsy, and haloperidol-induced catalepsy on mice were also investigated. Lastly, the forced swimming and tail suspension tests in mice were employed to screen the possible antidepressant effects of AZE. Results. AZE (100-3000 mg/kg) showed signs of central nervous system (CNS) depression under observation, with no lethality, $24 \mathrm{~h}$ after treatment in mice. AZE (100-1000 mg/kg) produced a significant decrease in the frequency of novelty- and apomorphine-induced locomotor activities in mice. The extract also significantly decreased the frequency and duration of apomorphine-induced climbing activities in mice. AZE, while failing to produce any cataleptic event in naïve mice, significantly enhanced haloperidol-induced catalepsy at a dose of $1000 \mathrm{mg} / \mathrm{kg}$. However, AZE did not produce any significant antidepressant effects in the test models employed. Conclusion. The extract of Albizia zygia exhibited an antipsychotic-like activity in mice.

\section{Introduction}

Albizia zygia (family Leguminosae-Mimosoideae) is a medium-sized semideciduous tree that can grow up to about $30 \mathrm{~m}$ high and widespread in tropical Africa, known locally in Ghana as "Okuro" among the Akans [1]. The wood obtained from the tree is used for indoor construction, veneer and plywood, boat and ship building, implements (e.g., pestles, hoe-handles), matches, and vehicle bodies. In the Ghanaian traditional medicine, the leaves of Albizia zygia are used in the management of mental troubles [2]. In other indigenous African traditional health systems, the bark sap is instilled in the eyes to treat eye infections and the bark decoction is also useful for the treatment of bronchial diseases, malaria, fever, and female sterility [3]. The pounded bark is applied topically to treat yaws, sores, wounds, and toothache. Leaf decoctions are administered to treat fever and diarrhoea. Ground roots of the plant are added to food to treat cough and as an expectorant. The root bark juice is also used on wounds to promote healing [3]. In Nigeria, some communities use the plant for the treatment of waist pain [4] and in Cameroon, decoction of the leaves and stem is used in the treatment of boils, diarrhoea, male sexual impotence, oedema, and fracture $[5,6]$. 
Three flavonoids $\left(4^{\prime}, 7\right.$-dihydroxyflavanone, $3^{\prime}, 4^{\prime}, 7$-trihydroxyflavone, and 3-O-methylfisetin $\left(3^{\prime}, 4^{\prime}, 7\right.$-trihydroxy-3methoxyflavone)) isolated from Albizia zygia were tested against Plasmodium falciparum $\mathrm{K} 1$ and only $3^{\prime}, 4^{\prime}, 7$-trihydroxyflavone showed potent antimalarial activity $\left(\mathrm{IC}_{50}\right.$ $0.078 \mu \mathrm{g} / \mathrm{ml}$ ) [7]. Hexane and methanol extract of Albizia zygia has demonstrated in vitro free radical scavenging and antioxidant effects [8]. The aqueous methanolic stem bark extract of Albizia zygia has been found to possess analgesic activity and low subacute toxicity [9]. Recently, the antipyretic and analgesic properties of the plant extracts have been demonstrated $[10,11]$.

In African countries such as Ghana, up to $80 \%$ of the population use traditional medicine for their primary health care, and these treatment options are less expensive and easily accessible [12]. The drug discovery paradigm involving the investigation of medicinal plants has produced successful results such as the isolation of reserpine from Rauwolfia serpentina which is known to have antipsychotic properties [13-15], in addition to its better known antihypertensive effect.

In our quest to provide pharmacological validation of the traditional use in mental health, the antipsychotic and antidepressant effects of an ethanolic extract of the leaves of Albizia zygia in mice were evaluated.

\section{Materials and Methods}

2.1. Chemicals and Reagents. Chlorpromazine hydrochloride (Renandin, France) and haloperidol (STEROP, Belgium) were obtained from local suppliers, whereas apomorphine hydrochloride was obtained from Macfarlan Smith Ltd., Scotland, UK.

2.2. Plant Collection and Extraction. Fresh leaves of the plant were collected from the Aburi Botanical Gardens, Aburi, Ghana, in March 2015 by a curator at the Ghana Herbarium, Department of Plant and Environmental Biology, University of Ghana, Legon, Accra, who identified and authenticated them. A voucher specimen (PA03/UGSOP/GH15) was deposited at the herbarium. The leaves were air-dried for seven days and powdered. A weighed amount of the powder was cold-macerated with $70 \% \mathrm{v} / \mathrm{v}$ of ethanol in water. The ethanolic extract was then evaporated to dryness under reduced pressure, labelled as AZE, and stored in a desiccator.

2.3. Qualitative Phytochemical Screening of AZE. AZE was screened for the presence of alkaloids, saponins, tannins, flavonoids, and other phytochemicals using standard qualitative colorimetric methods [16].

2.4. Animals and Husbandry. Female Imprint Control Region (ICR) mice (weighing 20-30 g), 6-8 weeks old, were obtained from the Department of Animal Experimentation, Noguchi Memorial Institute for Medical Research (NMIMR), University of Ghana, Legon, Accra. The mice were accommodated in groups of five in stainless steel cages (dimensions: $34 \mathrm{~cm} \times 47 \mathrm{~cm} \times 18 \mathrm{~cm}$ ) with soft wood chips as bedding and kept under laboratory conditions (temperature $22 \pm 2^{\circ} \mathrm{C}$, relative humidity 60-70\%, and 12-hour light-dark cycle). The mice were fed with normal commercial pellet diet (AGRIMAT, Kumasi) and given water ad libitum. All the behavioural testing was conducted from 8:00 to 15:00 GMT.

2.5. Irwin's Test. Irwin's test for primary observation of AZE in mice was done as previously described [17]. Briefly, mice were treated with AZE $(30,100,300,1000$, and $3000 \mathrm{mg} / \mathrm{kg}$, p.o.) and vehicle (distilled water, $10 \mathrm{ml} / \mathrm{kg}$, p.o.) as control. The mice were then observed $15,30,60,120$, and $180 \mathrm{~min}$ after administration of the extract/distilled water. The observation was repeated 24 hours later. The parameters, death, convulsions, sedation, excitation, jumping, abnormal gait (rolling, tiptoe), motor incoordination, loss of grasping, akinesia, catalepsy, loss of traction, loss of balance, forepaw treading, writhing, piloerection, stereotypies (sniffing, chewing, and head movements), head-twitches, scratching, altered respiration, aggression, altered fear, altered reactivity to touch, ptosis, exophthalmia, loss of righting reflex, loss of corneal reflex, analgesia, defecation/diarrhoea, salivation, lacrimation, and pupil diameter (myosis/mydriasis), were recorded when exhibited.

2.6. Open-Field Test: Novelty-Induced Behaviours. The extract/drug-induced locomotor and rearing behaviours were determined in an open-field observation box (dimensions: $25 \mathrm{~cm} \times 25 \mathrm{~cm} \times 30 \mathrm{~cm}$ ) made of transparent Perspex. The base of the maze has 16 squares $(6.5 \mathrm{~cm} \times 6.5 \mathrm{~cm})$ demarcated with a nontoxic permanent marker. The arena of the open field was also designated as (i) corner (one of the four corner squares); (ii) periphery (the squares along the walls); or (iii) centre (the 4 inner squares). In the investigation, groups of mice were treated with AZE $(100,300$, and $1000 \mathrm{mg} / \mathrm{kg}$, p.o.), chlorpromazine $1 \mathrm{mg} / \mathrm{kg}$ (i.p.), or vehicle (distilled water, $10 \mathrm{ml} / \mathrm{kg}$, p.o.). The selected doses of the extract were based on the findings from Irwin's test described above. Thirty minutes later, the mice were placed individually into the open-field observational box and their behaviour was recorded for 5 min using a camcorder (Everio ${ }^{\mathrm{TM}}$ Model, GZMG 130 U, JVC, Tokyo, Japan) suspended above the maze with the aid of a stand. Rearing behaviour was recorded when a mouse stood on its hind limbs and placed the forelimbs against the wall of the observation cage (supported rearing) or in free air (unsupported rearing). The number of rears (both supported and unsupported) was tracked for $5 \mathrm{~min}$. In addition, the number of times a mouse crosses any of the lines demarcating the base of the maze (i.e., line-crossing) was counted as a representation of locomotor activity. The total frequency and duration spent in the corner and periphery or central portions of the observation set-up by the mice were also recorded.

2.7. Open-Field Test: Apomorphine-Induced Behaviours. In the open-field paradigm, as described above, mice were pretreated with AZE (100, 300, or $1000 \mathrm{mg} / \mathrm{kg}$, p.o.), chlorpromazine $(0.1,0.3$, or $1.0 \mathrm{mg} / \mathrm{kg}$, i.p.), or vehicle (distilled water, $10 \mathrm{ml} / \mathrm{kg}$, p.o.) and $30 \mathrm{~min}$ later, they received apomorphine ( $2 \mathrm{mg} / \mathrm{kg}$, i.p.). The mice were then placed in the open-field test chamber. A no-apomorphine vehicle group was also 
included. The events were recorded with a camcorder for $30 \mathrm{~min}$ and frequency of rearing and line-crossing behaviours was tracked for each mouse. Also the total frequency and duration the mice spent in the corner, periphery, or central portions of the observation set-up were recorded.

2.8. Cage Climbing Test. The method as described previously was adopted [18]. In brief, mice were treated with AZE $(100,300$, and $1000 \mathrm{mg} / \mathrm{kg}$, p.o.), haloperidol (0.1, 0.3, and $1 \mathrm{mg} / \mathrm{kg}$, i.p.), or vehicle (distilled water, $10 \mathrm{ml} / \mathrm{kg}$, p.o.). After $30 \mathrm{~min}$, they were injected with apomorphine $(2 \mathrm{mg} / \mathrm{kg}$, i.p.). The mice were then immediately placed individually into an all wire-meshed cage (mesh size: $1 \mathrm{~cm} \times 1 \mathrm{~cm}$; dimensions $=27 \mathrm{~cm} \times 20 \mathrm{~cm} \times 20 \mathrm{~cm}$ ) and their climbing behaviour recorder with a camcorder which was placed above the cage for $30 \mathrm{~min}$ after apomorphine injection. The frequency and duration of climbing were tracked from the recorded video.

\subsection{Catalepsy: Extract/Drug-Induced Motor Effect. An} extract/drug-induced cataleptic test in mice was conducted as previously described $[19,20]$. The set-up used in this test consists of a Perspex rod elevated with support to a height of $3.5 \mathrm{~cm}$. Mice pretreated with the AZE $(100,300$, and $1000 \mathrm{mg} / \mathrm{kg}$, p.o), haloperidol (0.1, 0.3 , and $1.0 \mathrm{mg} / \mathrm{kg}$, i.p.), or vehicle were tested individually on this set-up 15, 30, and $60 \mathrm{~min}$ after treatment. The time a mouse spent when placed on the rod with its forepaws was recorded. The test ended when the animal removed its forepaws from the rod unto the floor or climbed the rod.

2.10. Potentiation/Inhibition of Haloperidol-Induced Catalepsy. The effect of AZE on haloperidol-induced catalepsy was performed as previously described [20,21]. Mice were pretreated with AZE $(100,300$, or $1000 \mathrm{mg} / \mathrm{kg}$, p.o.) or vehicle (distilled water, $0.01 \mathrm{ml} / \mathrm{kg}$, p.o.). Thirty minutes later, each mouse was treated with haloperidol $1 \mathrm{mg} / \mathrm{kg}$ (i.p.) and tested for catalepsy as described above.

2.11. Forced Swimming Test (FST). This procedure was carried out using published methods with modifications [22-24]. Briefly, mice $(n=5-10)$ were pretreated with AZE (100, 300 , and $1000 \mathrm{mg} / \mathrm{kg}$, p.o.), fluoxetine (3, 10, and $30 \mathrm{mg} / \mathrm{kg}$, p.o.), or vehicle (10 ml/kg of normal saline, p.o.), one hour (p.o.) or $30 \mathrm{~min}$ (i.p.) before being placed individually in polypropylene cylinders (height $25 \mathrm{~cm}$, diameter $10 \mathrm{~cm}$ ) containing water to a height of $15 \mathrm{~cm}$, maintained at $32^{\circ} \mathrm{C}$. With a public domain software JWatcher, version 1.0 (University of California, Los Angeles, USA, and Macquarie University, Sydney, Australia), behavioural assessment was measured during the 5-minute test period. Immobility behaviours (floating passively in the water without active movement except for twitches, shivers, or corrective wall-bouncing), swimming behaviours (movement of the hind limbs or tail resulting in a propulsive force or swimming motions, more than necessary, to solely maintain their head above water), and climbing behaviours (active movements in and out of the water with forepaws, usually directed against the walls) of the mice were scored.
2.12. Tail Suspension Test. The tail suspension test (TST) was carried out according to previous descriptions with modifications $[24,25]$. Animals were randomly grouped in a similar fashion as in the FST and given AZE $(100,300$, and $1000 \mathrm{mg} / \mathrm{kg}$, p.o.), fluoxetine (3, 10, and $30 \mathrm{mg} / \mathrm{kg}$, p.o.), or vehicle (10 $\mathrm{ml} / \mathrm{kg}$ of normal saline, p.o.), one hour after oral administration and $30 \mathrm{~min}$ after intraperitoneal injection. Mice were individually suspended by the tail by tape wrapped around the distal third of the tail such that the body hung on a horizontal ring stand bar is raised $30 \mathrm{~cm}$ above the floor. Test sessions lasted $5 \mathrm{~min}$ and were videotaped. Behaviours rated were as follows: (1) immobility: a mouse was judged to be immobile when it performs no active behaviour, (2) swinging: a mouse was judged to be swinging when it continuously moved its paws in the vertical position while keeping its body straight and/or it moved its body from side to side, and (3) curling: a mouse was judged to be curling when it engaged in active twisting movements of the entire body.

\section{Results}

3.1. Qualitative Phytochemical Screening of AZE. Alkaloids, flavonoids, tannins, saponins, and anthraquinone glycosides were found to be present in AZE.

3.2. Irwin's Test. AZE $(100,300,1000$, and $3000 \mathrm{mg} / \mathrm{kg})$ showed signs of CNS depression under observation. Extracttreated mice (at all dose levels) showed dose and time dependent sedation which lasted 60 minutes. There were no signs of convulsion and no mouse died after 24 hours suggesting $\mathrm{LD}_{50}$ is above $3000 \mathrm{mg} / \mathrm{kg}$.

3.3. Open-Field Test: Novelty-Induced Behaviours. AZE (100, 300 , and $1000 \mathrm{mg} / \mathrm{kg}$, p.o.) significantly decreased the frequencies of rearing $\left(P<0.0001, F_{4,15}=22.82\right.$, Figure 1) and line-crossing $\left(P<0.0001, F_{3,16}=11.83\right.$, Figure 1$)$ in the mice treated, in comparison with the vehicle-treated group. The decrease in the frequency of the rearing behaviour was dose-dependent. In the 5 min test period, the AZE $(100,300$, and $1000 \mathrm{mg} / \mathrm{kg}$, p.o.) significantly increased the frequency of centre, periphery, and corner entry $\left(P=0.0002, F_{4,20}=\right.$ 9.366; Figure 2(a), $P<0.0001, F_{4,20}=19.33$; Figure 2(b), and $P<0.0001, F_{4,20}=16.62$; Figure 2(c), resp.) compared to the vehicle-treated group. The extract significantly decreased the time spent by mice in the centre and corner $\left(P=0.0013, F_{4,17}\right.$ $=7.268$; Figure 2(a) and $P=0.0008, F_{4,20}=7.861$; Figure 2(c), resp.) of the open field. Also, AZE produced a decrease in the time spent by mice in the periphery $\left(P=0.1469, F_{4,20}=1.917\right.$; Figure 2(b)) of the open field, but this was not significant.

3.4. Open-Field Test: Apomorphine-Induced Behaviours. Apomorphine $(2 \mathrm{mg} / \mathrm{kg}$, i.p.) produced a characteristic increase in rearing and locomotor activity in the vehicletreated group when compared with the vehicle-alone-treated group of mice (i.e., no apomorphine) (Figures 3(a) and $3(b))$. There was a significant and dose-dependent decrease in the frequency of line-crossing behaviour $(P=0.0002$, $F_{3,9}=20.90$, Figure $\left.3(\mathrm{~b})\right)$ in the mice treated with AZE 


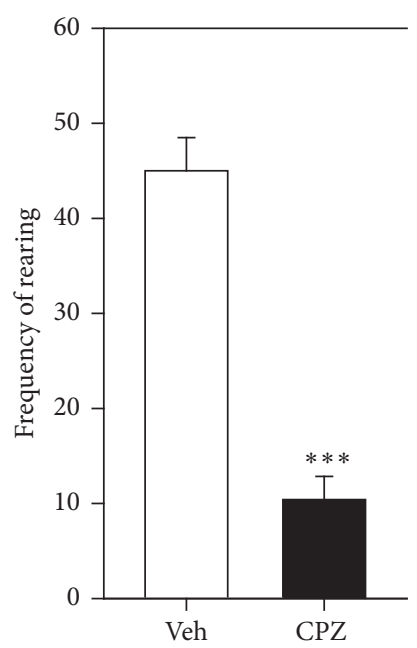

(a)

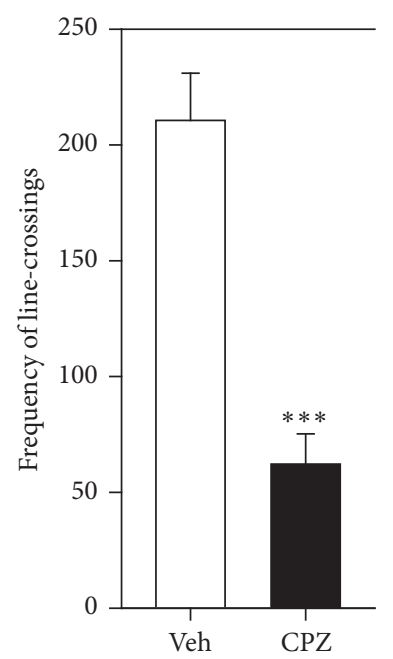

(c)

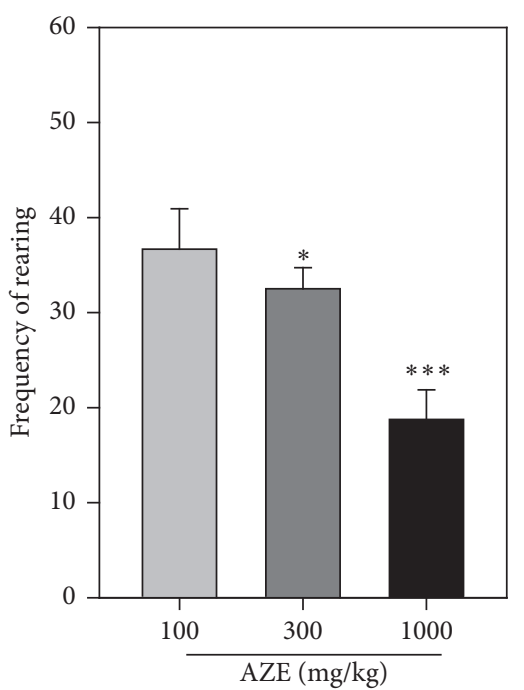

(b)

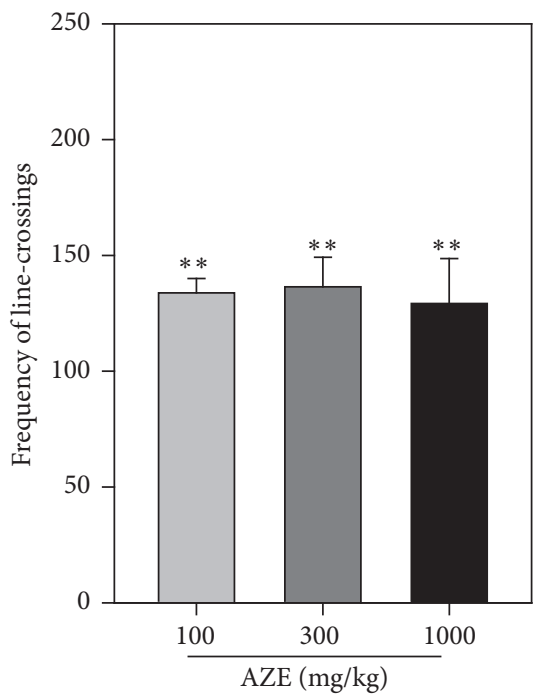

(d)

FiguRE 1: Frequency of rearing ((a) and (b)) and line-crossings ((c) and (d)) of mice treated with chlorpromazine (CPZ; $1 \mathrm{mg} / \mathrm{kg}$, i.p.), AZE $(100,300$, and $1000 \mathrm{mg} / \mathrm{kg}$, p.o.), and vehicle (Veh) when observed for $5 \mathrm{~min}$ in an open-field paradigm. Data are mean \pm SEM $(n=5)$. ${ }^{*} P \leq 0.05,{ }^{* *} P \leq 0.01$, and ${ }^{* * *} P \leq 0.001$ compared with vehicle group (one-way ANOVA followed by a Dunnett's multiple comparison post hoc test).

in comparison to the vehicle-treated mice. However, AZE failed to elicit any significant change in the frequency of rearing in the mice treated with it $\left(P=0.2217, F_{3,10}=\right.$ 1.741, Figure 3(a)). Chlorpromazine significantly decreased apomorphine-induced rearing $\left(P=0.0065, F_{3,15}=6.067\right.$, Figure $3(\mathrm{a}))$ and locomotor activity $\left(P=0.007, F_{3,12}=6.58\right.$, Figure $3(\mathrm{~b})$ ) in mice that were pretreated with it. The decrease in rearing activity by CPZ was dose-dependent, whereas that of the line-crossing was not. In comparison to the vehicle-treated group, AZE (100, 300, and $1000 \mathrm{mg} / \mathrm{kg}$, p.o.) decreased, but not significantly, the frequency of centre entry $\left(P=0.5044, F_{4,18}=0.8636\right.$; Figure $\left.4(\mathrm{a})\right)$ but significantly reduced the time spent by mice in the centre $(P=0.0077$, $F_{4,15}=5.228$; Figure 4(a)) of the open field. The extract significantly increased the frequency of periphery entry
$\left(P=0.0228, F_{4,17}=3.761\right.$; Figure $\left.4(\mathrm{~b})\right)$ and significantly decreased the time spent by animals in the periphery $\left(P=0.0054, F_{4,17}=5.400\right.$; Figure 4(b) $)$ of the open field. AZE also increased, but not significantly, the frequency of entries into the corner $\left(P=0.1168, F_{4,18}=2.146\right.$; Figure 4(c) $)$ but produced no significant change in the time spent by mice in the corner $\left(P=0.1290, F_{4,19}=2.043\right.$; Figure $\left.4(c)\right)$ of the open field.

3.5. Cage Climbing Test. Apomorphine induced a characteristic increase in the total frequency (Figure 5(a)) and duration (Figure 5(b)) of climbing of the wire-meshed cage by the animals. AZE $(100,300$, and $1000 \mathrm{mg} / \mathrm{kg}$, p.o.) significantly reduced the total frequency $\left(P<0.0001, F_{3,16}=247.3\right.$; Figure 5(a)) and duration $\left(P<0.0001, F_{3,12}=32.79\right.$; 


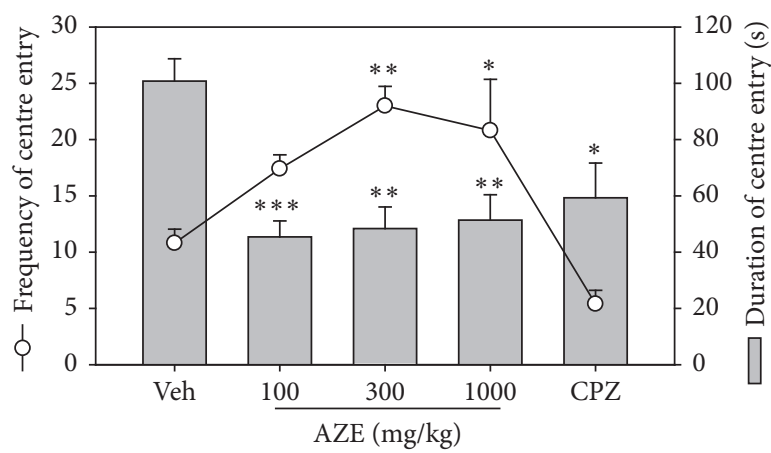

(a)

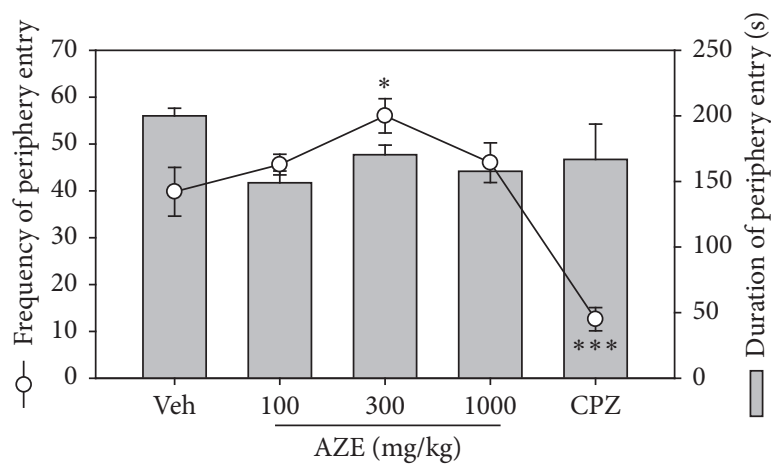

(b)

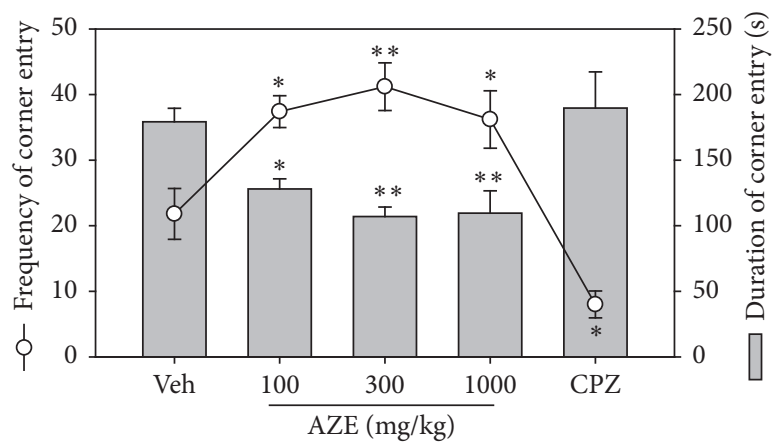

(c)

FIGURE 2: Effects of AZE (100-1000 mg/kg) on the frequency (line graph) and duration (column graphs) of centre entry (a), periphery entry (b), and corner entry (c). Each point represents mean \pm SEM $(n=5) .{ }^{*} P<0.05,{ }^{* *} P<0.01$, and ${ }^{* * *} P<0.001$, compared to vehicle-treated group (one-way ANOVA followed by Dunnett's post hoc test).

TABLE 1: $\mathrm{ED}_{50}$ values $(\mathrm{mg} / \mathrm{kg}) \pm \mathrm{SEM}$ of AZE and haloperidol (HAL) on the frequency and total duration of apomorphine-induced cage climbing in mice.

\begin{tabular}{lcr}
\hline & AZE & HAL \\
\hline Frequency & $979.4 \pm 1.35$ & $0.1391 \pm 1.07$ \\
Duration & $240.8 \pm 0.46$ & $0.1047 \pm 1.61$ \\
\hline
\end{tabular}

Figure $5(\mathrm{~b})$ ) of cage climbing in the treated mice, but not in the dose-dependent manner. Haloperidol (HAL) $(0.1,0.3$, and $1 \mathrm{mg} / \mathrm{kg}$, i.p.) significantly and dose-dependently reduced the total frequency $\left(P<0.0001, F_{3,16}=172.1\right.$, Figure 5(a) $)$ and duration of cage climbing $\left(P<0.0001, F_{3,15}=146.7\right.$, Figure 5(b)). Comparison of the $\mathrm{ED}_{50}$ values of $\mathrm{AZE}$ and haloperidol revealed that HAL was more potent than AZE
(Table 1). However, the effect of AZE at dose of $300 \mathrm{mg} / \mathrm{kg}$, p.o., which was the most potent $(P<0.0001)$ extract dose in reducing climbing behaviour, was comparable to haloperidol at dose $1 \mathrm{mg} / \mathrm{kg}$, i.p.

3.6. Catalepsy: Extract/Drug-Induced Motor Effects. AZE $(100,300$, and $1000 \mathrm{mg} / \mathrm{kg})$ did not produce any cataleptic 

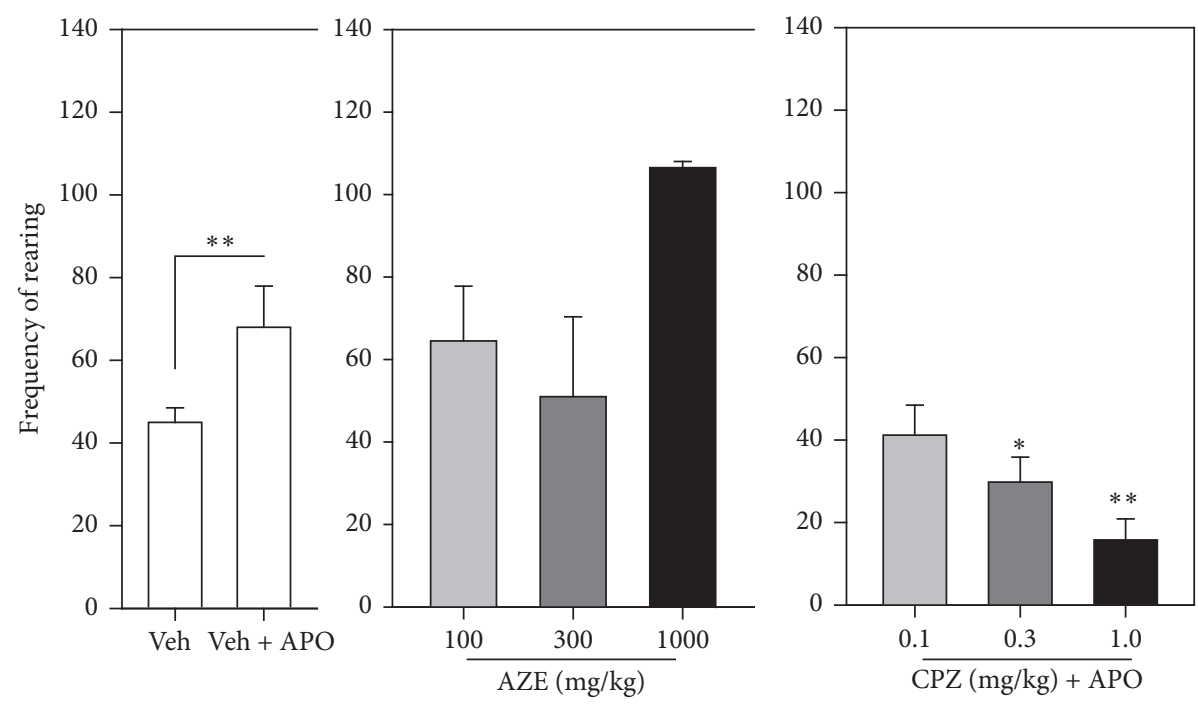

(a)
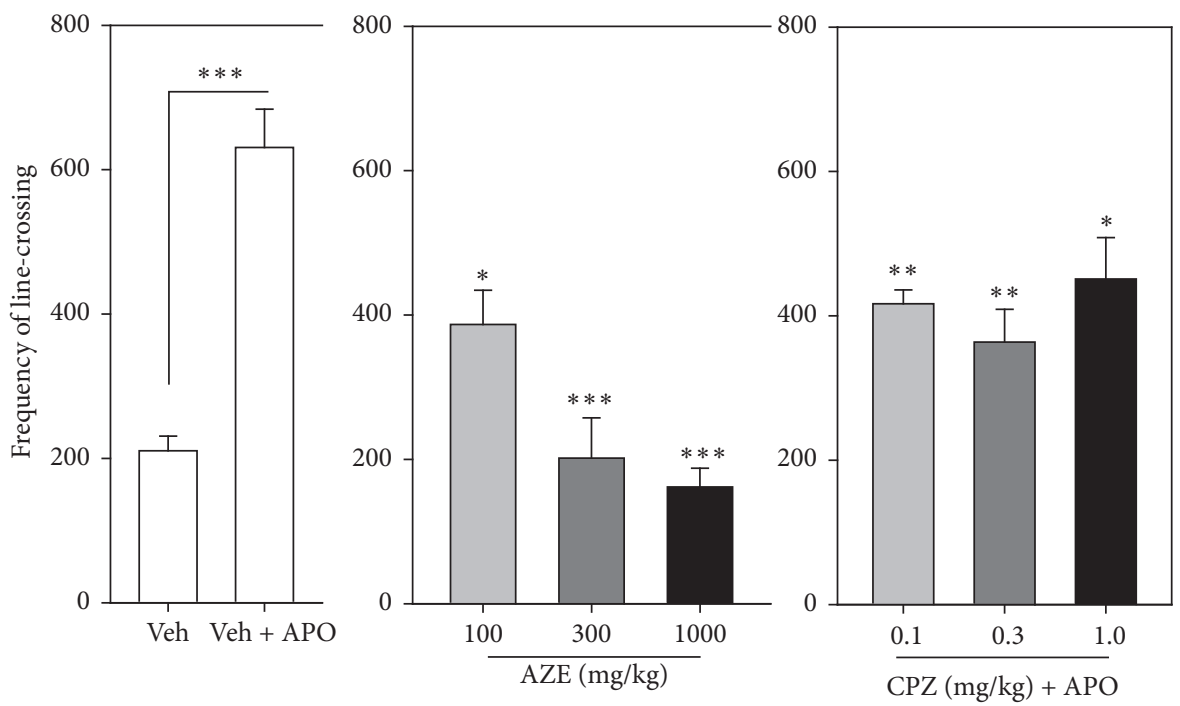

(b)

Figure 3: Effect of AZE (100, 300, and $1000 \mathrm{mg} / \mathrm{kg}$, p.o.), CPZ (0.1, 0.3, and $1.0 \mathrm{mg} / \mathrm{kg}$, i.p.), and vehicle (Veh) (distilled water, 0.01 ml/kg, p.o.) on the frequency of rearing (a) and line-crossings (b) of mice, $30 \mathrm{~min}$ after apomorphine (APO) ( $2 \mathrm{mg} / \mathrm{kg}$, i.p.) treatment in an open-field paradigm. Data are mean $\pm \operatorname{SEM}(n=5) .{ }^{*} P \leq 0.05,{ }^{* *} P \leq 0.01$, and ${ }^{* * *} P \leq 0.001$ compared with Veh + APO group (one-way ANOVA followed by a Dunnett's multiple comparison post hoc test).

behaviour $\left(P=0.23, F_{3,16}=1.753\right.$, Table 2$)$ in the mice treated. Haloperidol (0.1, 0.3, and $1 \mathrm{mg} / \mathrm{kg})$, however, exhibited a significant and dose-dependent cataleptic behaviour in the treated mice $\left(P=0.01, F_{3,16}=5.209\right.$, Table 2$)$.

\subsection{Potentiation/Inhibition of Haloperidol-Induced Catalepsy.} AZE 100 and $300 \mathrm{mg} / \mathrm{kg}$ inhibited the cataleptic effect of haloperidol $(1 \mathrm{mg} / \mathrm{kg})$ throughout the $60 \mathrm{~min}$ after haloperidol treatment. However, AZE $1000 \mathrm{mg} / \mathrm{kg}$ increased significantly the haloperidol-induced catalepsy, 30 and $60 \mathrm{~min}$ after haloperidol treatment (Figure 6(a)). Overall, there was a significant difference $\left(P=0.0087, F_{3,12}=6.200\right.$, Figure 6(b) $)$ between the AZE- and vehicle-treated mice in this test and only AZE $1000 \mathrm{mg} / \mathrm{kg}$ significantly increased the haloperidolinduced cataleptic behaviour $(P<0.01$, Figure 6(b))

3.8. Forced Swimming Test. AZE (100, 300, and $1000 \mathrm{mg} / \mathrm{kg}$, p.o.) administered $60 \mathrm{~min}$ before the test period produced no significant reduction in the duration of immobility $(P=$ $0.6480, F_{3,16}=0.5618$; Figure $7(\mathrm{a})$ ) of mice in the FST. Fluoxetine (FLX) (3, 10, and $30 \mathrm{mg} / \mathrm{kg}$, p.o.) significantly reduced the duration of immobility $\left(P<0.0001, F_{3,18}=151.1\right.$; Figure $7(b))$ of mice in a dose-dependent manner relative to the vehicle-treated group. 


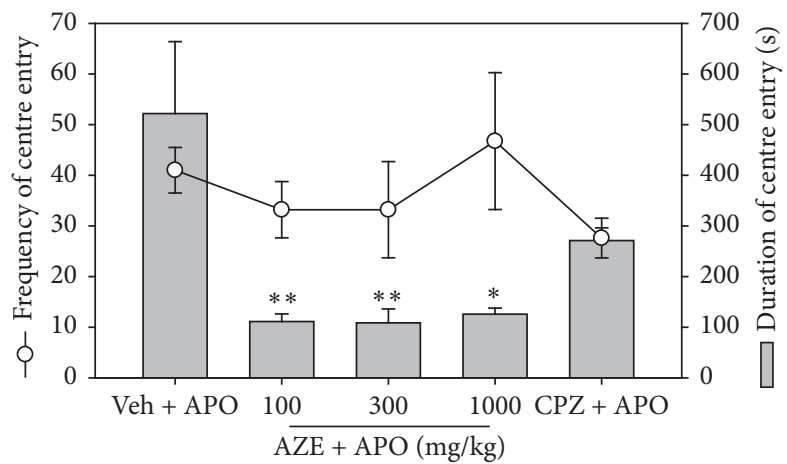

(a)

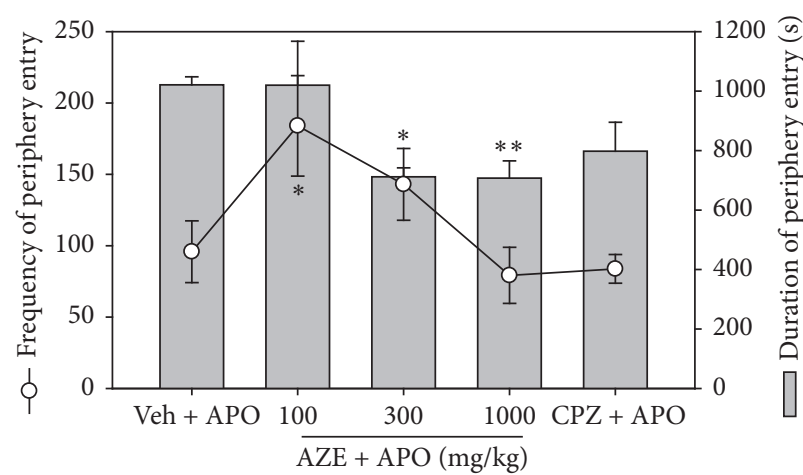

(b)

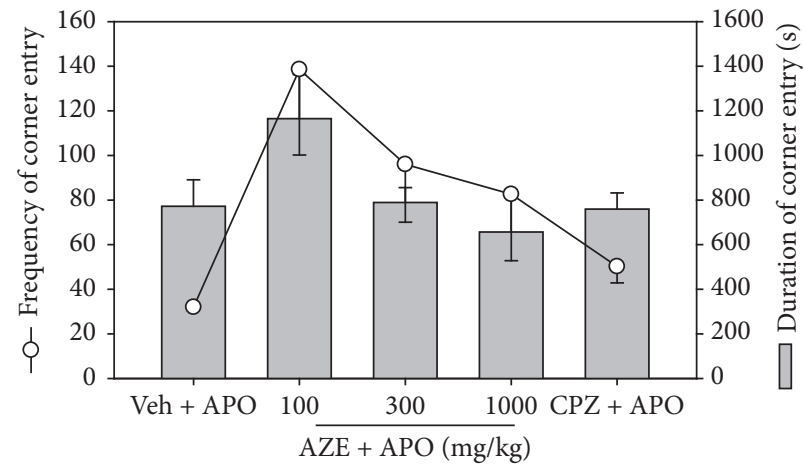

(c)

Figure 4: Effect of AZE (100, 300, and $1000 \mathrm{mg} / \mathrm{kg}$, p.o.), CPZ (1.0 mg/kg, i.p.), and vehicle (Veh) (distilled water, $0.01 \mathrm{ml} / \mathrm{kg}$, p.o.) on the frequency (line graph) and duration (column graphs) of centre entry (a), periphery entry (b), and corner entry (c), 30 min after apomorphine (APO) $\left(2 \mathrm{mg} / \mathrm{kg}\right.$, i.p.) treatment in an open-field paradigm. Data are mean \pm SEM $(n=5) .{ }^{*} P \leq 0.05$ and ${ }^{* *} P \leq 0.01$ compared with Veh + APO group (one-way ANOVA followed by a Dunnett's multiple comparison post hoc test).

TABLE 2: Effect of extracts AZE, haloperidol (HAL), and vehicle on the duration of catalepsy. Data are mean \pm SEM $(n=5) .{ }^{*} P \leq 0.05$, ${ }^{* *} P \leq 0.01$, compared with vehicle group (two-way ANOVA followed by a Bonferroni's post hoc test).

\begin{tabular}{lccc}
\hline Treatment $(\mathrm{mg} / \mathrm{kg})$ & 15th min & $\begin{array}{c}\text { Time }(\mathrm{s}) \\
\text { 30th min }\end{array}$ & 60th min \\
\hline Vehicle & $0.000 \pm 0.00$ & $0.00 \pm 0.00$ & $0.00 \pm 0.00$ \\
\hline AZE 100 & $0.000 \pm 0.00$ & $1.398 \pm 0.87$ & $1.398 \pm 1.09$ \\
AZE 300 & $0.000 \pm 0.00$ & $0.200 \pm 0.13$ & $1.300 \pm 1.07$ \\
AZE 1000 & $0.400 \pm 0.40$ & $0.000 \pm 0.00$ & $0.000 \pm 0.00$ \\
\hline HAL 0.3 & $34.187 \pm 8.01$ & $87.902 \pm 33.81$ & $108.892 \pm 32.84$ \\
HAL 1.0 & $154.340 \pm 42.16^{* *}$ & $153.273 \pm 52.08^{*}$ & $125.403 \pm 55.14^{*}$ \\
HAL 3.0 & $162.660 \pm 46.41^{* *}$ & $179.510 \pm 50.24^{* *}$ & $192.122 \pm 40.87^{* *}$ \\
\hline
\end{tabular}



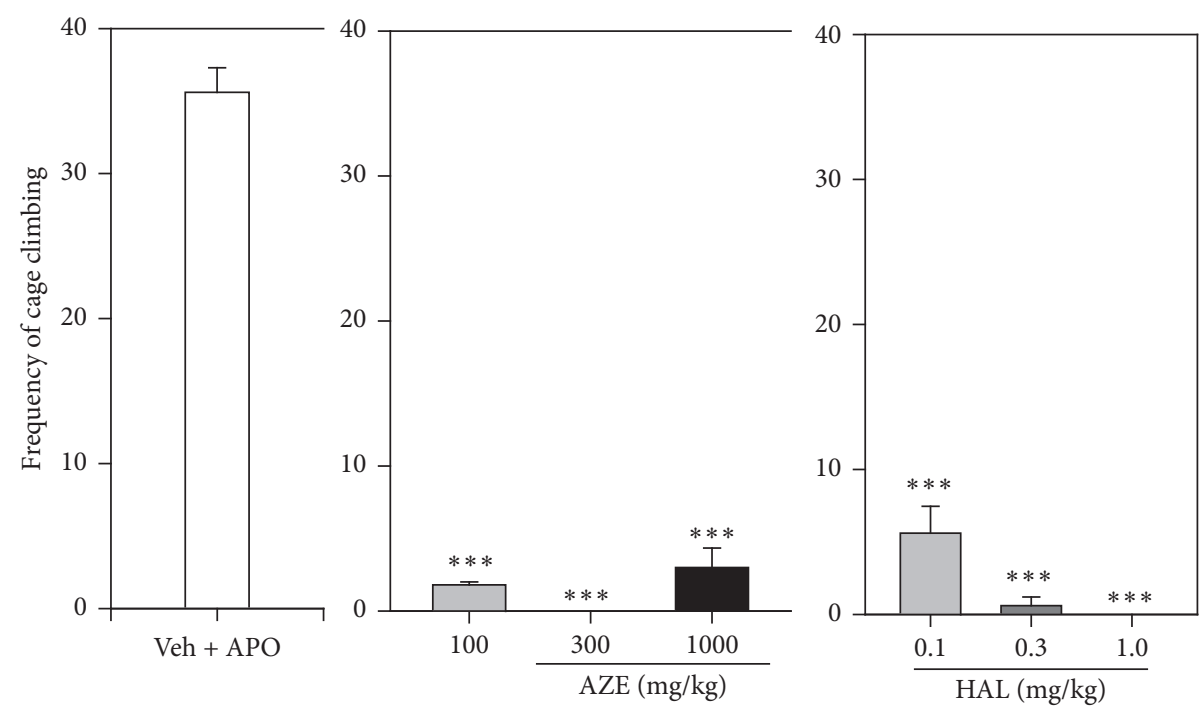

(a)
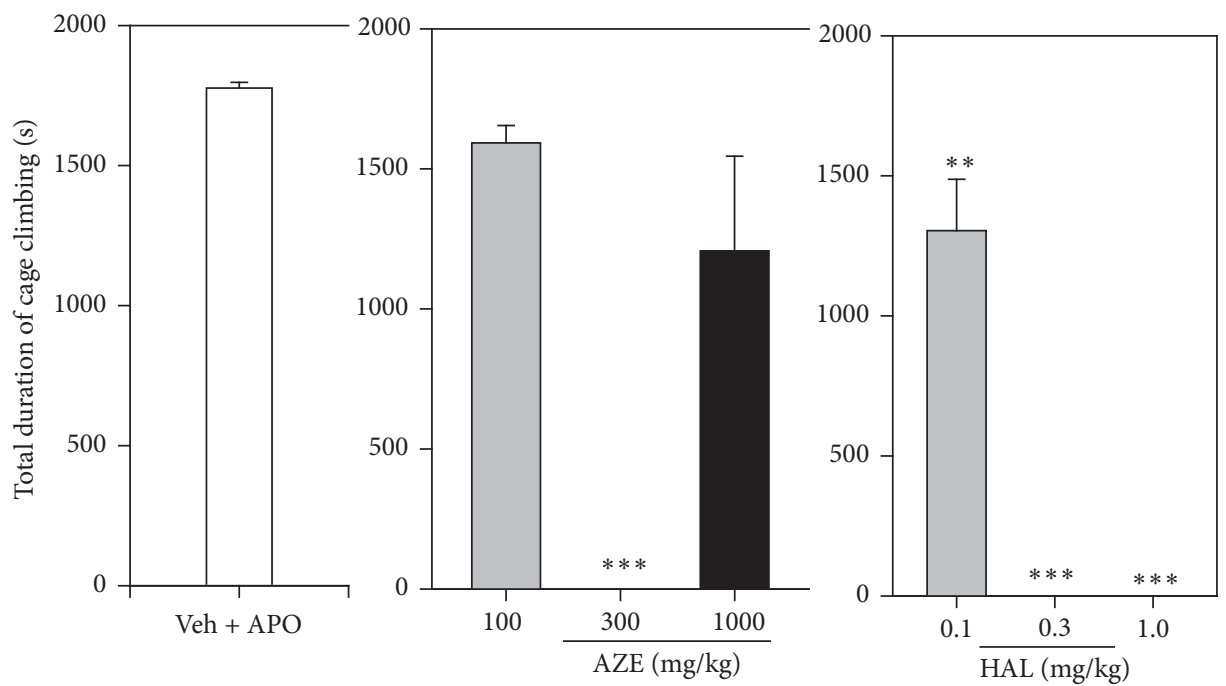

(b)

Figure 5: Effect of AZE (100,300, and $1000 \mathrm{mg} / \mathrm{kg}$, p.o.), $\operatorname{HAL}(0.1,0.3,1.0 \mathrm{mg} / \mathrm{kg}$, i.p.), and vehicle (Veh) on the total frequency and duration of cage climbing of mice, $30 \mathrm{~min}$ after apomorphine (APO) $(2 \mathrm{mg} / \mathrm{kg}$, i.p. $)$ treatment. Data are mean $\pm \operatorname{SEM}(n=5) .{ }^{* *} P \leq 0.01$ and ${ }^{* * *} P \leq 0.001$ compared with Veh + APO group (one-way ANOVA followed by a Dunnett's multiple comparison post hoc test).

3.9. Tail Suspension Test. AZE (100, 300, and $1000 \mathrm{mg} / \mathrm{kg}$, p.o.) administered $60 \mathrm{~min}$ prior to the test period failed to produce any reduction in the duration of immobility $(P=$ $0.8600, F_{3,16}=0.2502$; Figure $8(\mathrm{a})$ ) of mice in the TST. Fluoxetine (FLX) (3, 10, and $30 \mathrm{mg} / \mathrm{kg}$, p.o.), as expected, significantly and dose-dependently reduced the duration of immobility $\left(P<0.0001, F_{3,18}=61.74\right.$; Figure $\left.8(\mathrm{~b})\right)$ of mice with respect to the vehicle-treated group.

\section{Discussion}

The present study describes an antipsychotic and antidepressant potential of a hydroethanolic extract of the leaves of Albizia zygia (AZE) in murine models of psychosis and depression. The experimental procedures were done to rationalise the traditional uses of the plant in mental health. The behavioural effects of Albizia zygia in mice were examined. Mice were used as the experimental subject because they are similar to humans at the anatomical, cellular, biochemical, and molecular level and also share with humans similar brain functions such as anxiety, hunger, circadian rhythm, aggression, memory, sexual behaviour, and other emotional responses [26]. The findings of this study provide initial evidence that AZE possesses antipsychotic-like effects. However, AZE seem to be devoid of antidepressant-like activity, as seen from the findings of the effects of AZE on the murine models of depression employed.

A preliminary investigation of the effects of the AZE in Irwin's tests, novelty-induced rearing, and locomotor activity demonstrates that the extract is sedative and that it decreases 


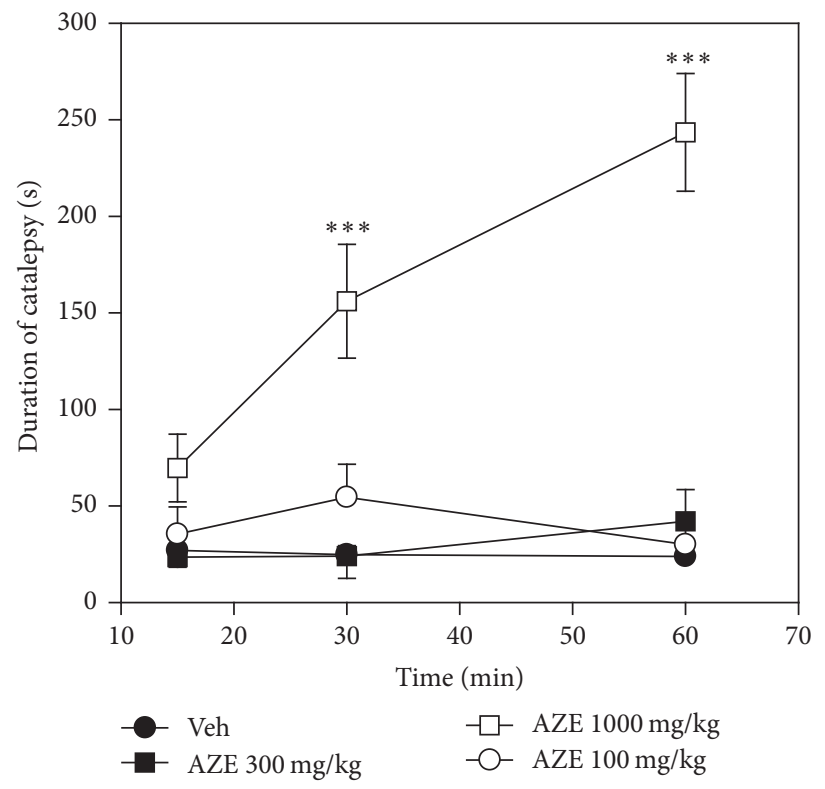

(a)

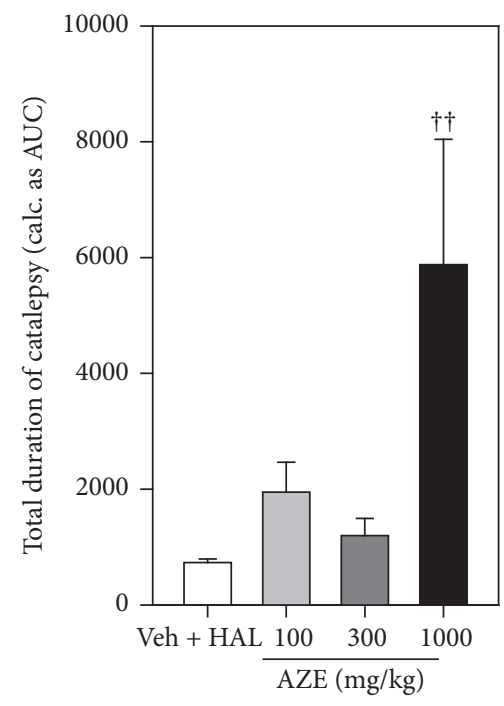

(b)

FIGURE 6: Effects of AZE on haloperidol- (HAL-) induced catalepsy in mice. Paneled graph (a) is the time-course effects 15, 30 , and 60 min after haloperidol administration. Column graph (b) is the total duration of catalepsy (calculated as AUCs from the time-course graphs). Data are mean $\pm \operatorname{SEM}(n=5) .{ }^{* * *} P \leq 0.001$ compared with vehicle group (two-way ANOVA followed by Bonferroni post hoc test). ${ }^{\dagger \dagger} P \leq 0.01$ compared with vehicle group (one-way ANOVA followed by a Dunnett's multiple comparison post hoc test).

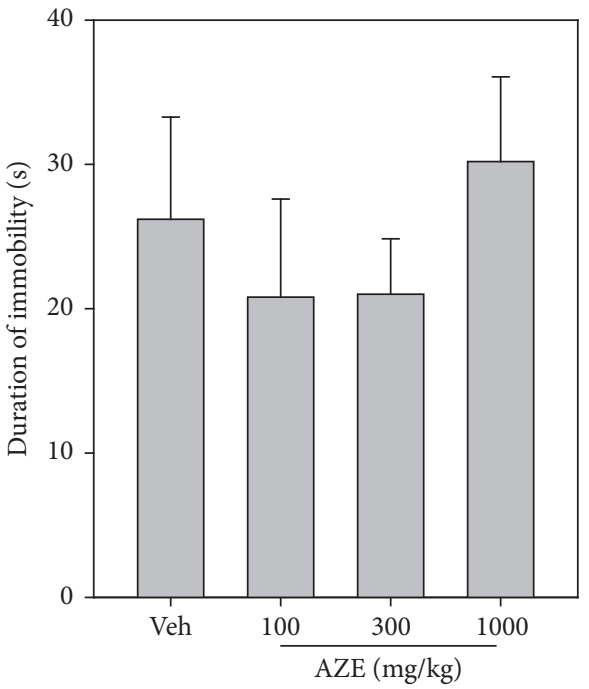

(a)

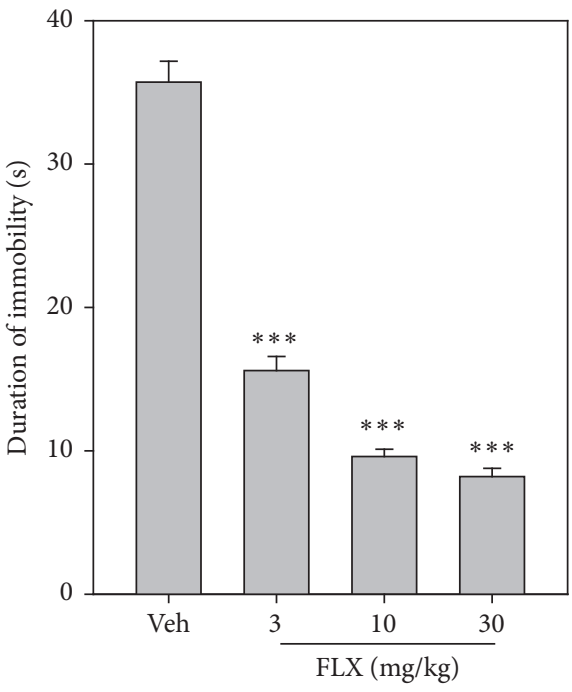

(b)

FIGURE 7: Effects of AZE (100-1000 mg/kg) (a) and FLX (3-30 mg/kg) (b) on the duration of immobility in the FST. Each point represents mean $\pm \operatorname{SEM}(n=5) .{ }^{* * *} P<0.001$, compared to vehicle-treated group (one-way ANOVA followed by Dunnett's post hoc test).

exploratory behaviour of the pretreated mice. These effects exhibited by AZE do not necessarily suggest an antipsychotic activity, though most antipsychotic agents produce similar effects in animals [27].

Stimulation of cerebral dopaminergic activity can produce psychosis de novo in some patients and psychosis has long been associated with increased cerebral dopaminergic activity. This role of dopamine in psychosis is supported by biochemical findings, clinical and imaging studies [28-31]. The clinical efficacy of most antipsychotic drugs, especially those effective against the positive psychotic symptoms such as hallucinations and delusions, may be linked to dopamine $\mathrm{D}_{2}$ receptor antagonism [32]. Murine models of psychosis used for screening antipsychotic drugs are based on the neurochemical hypothesis of schizophrenia, involving mainly the neurotransmitters, dopamine and glutamate [33]. The 


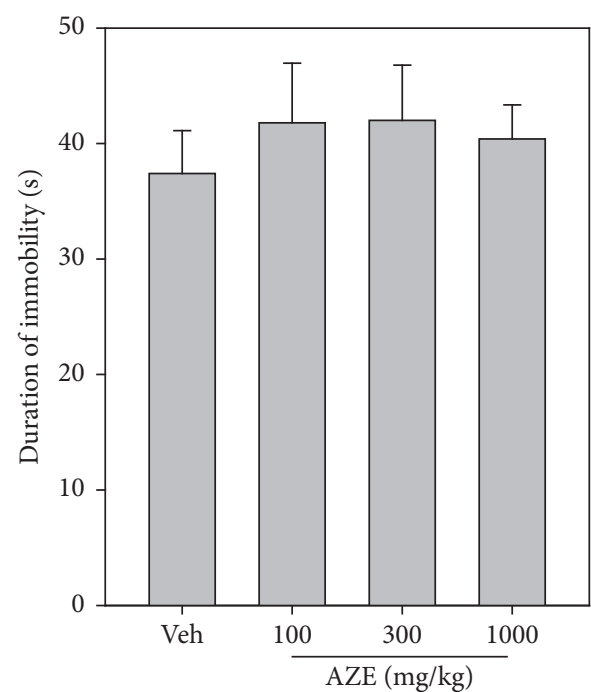

(a)

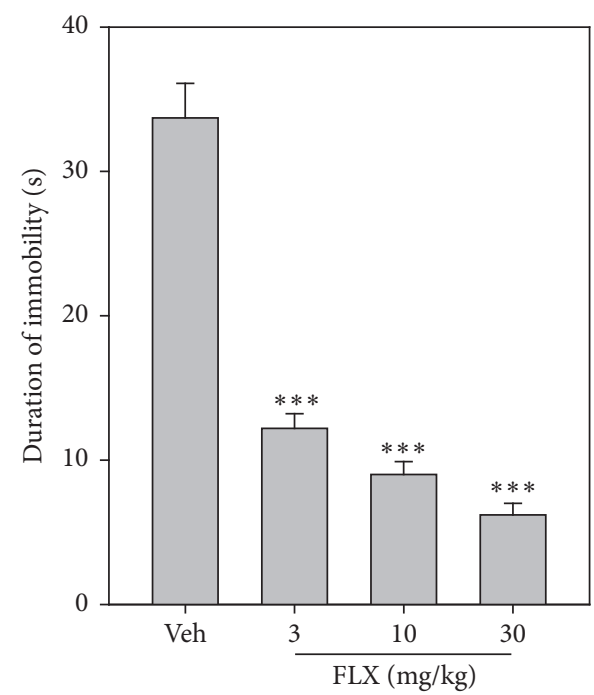

(b)

FIGURE 8: Effects of AZE (100-1000 mg/kg) (a) and FLX (3-30 mg/kg) (b) on the duration of immobility in the TST. Each point represents mean $\pm \operatorname{SEM}(n=5) .{ }^{* * *} P<0.001$, compared to vehicle-treated group (one-way ANOVA followed by Dunnett's post hoc test).

dopamine-based models usually use apomorphine, a direct dopamine agonist, or amphetamine, a drug that increases the release of dopamine and blocks its reuptake [34]. In this study, psychosis in the murine models was induced by administration of apomorphine which, being a nonselective dopamine agonist, elicits behavioural responses in animals by activating dopamine $\mathrm{D}_{1}$ and $\mathrm{D}_{2}$ receptors in the brain $[35,36]$. Activation of these dopamine receptors is known to increase locomotor activity [37], stereotyped behaviours [38], rearing/grooming [39], and cage climbing behaviours $[40,41]$.

The apomorphine-induced cage climbing test is a widely used test for screening antipsychotic drugs [18, 40, 42]. It has predictive validity for antipsychotic drugs that normalize the hyperactivity and stereotypic behaviour in that almost all antipsychotics dose-dependently antagonize apomorphineinduced cage climbing behaviour of mice [42]. Mice treated with low doses of apomorphine tend to adopt a vertical position and try to climb walls. Apomorphine induces climbing behaviour in mice by activating both dopamine $\mathrm{D}_{1}$ and $D_{2}$ receptors in the striatum [42]. Activation of either dopamine $\mathrm{D}_{1}$ or $\mathrm{D}_{2}$ receptors does not induce climbing behaviour; instead, activation of both receptors is required to produce climbing behaviour [43]. Therefore, it follows that antagonism of apomorphine-induced climbing behaviour is achieved by blocking either or both dopamine $\mathrm{D}_{1}$ and $\mathrm{D}_{2}$ receptors. Apomorphine induces a peculiar climbing behaviour in mice characterized initially by rearing and then spontaneous climbing activity. In the present study, acute pretreatment of AZE $(100,300$, and $1000 \mathrm{mg} / \mathrm{kg})$ in mice showed a significant but not dose-dependent decrease in frequency of climbing and climbing time induced by apomorphine compared to the vehicle-treated group. Haloperidol, the reference drug, significantly and dose-dependently reduced the climbing behaviour of mice as expected. AZE was less potent than HAL in reducing the apomorphine-induced climbing behaviour of mice as indicated by the $\mathrm{ED}_{50}$ values. However, the effects of AZE at dose of $300 \mathrm{mg} / \mathrm{kg}$ p.o. on climbing behaviour were comparable to haloperidol at dose of $1 \mathrm{mg} / \mathrm{kg}$ i.p. Based on these findings, it may be concluded that AZE produces antipsychotic activity which may be mediated through the antagonism of either or both of dopamine $\mathrm{D}_{1}$ and $\mathrm{D}_{2}$ receptors in the striatum of the brain.

Catalepsy test in rodents is a predictive tool for detecting the extrapyramidal side effects (EPS) of antipsychotic drugs [44]. EPS is a key side effect that is known to account for the discontinuation of antipsychotic drug use in patients [45]. Consequently, current research for new antipsychotic drug discovery is focused on agents with minimal or no EPS in addition to clinical efficacy $[45,46]$. Catalepsy in laboratory animals is defined as a failure to correct an externally imposed posture and the test entails measuring the latency for the animal to remove itself from the unfamiliar and uncomfortable position $[19,47]$. AZE's lack of catalepsy in the mice over the entire $60 \mathrm{~min}$ after administration period is an indication that it may not produce any significant EPS. However, this claim can be substantiated following the determination of the incidence of catalepsy after a chronic administration of the AZE. The extract, at the highest dose used in the study, produced a significant increase in haloperidol-induced catalepsy, suggesting it may have the ability to cause this side effect at higher doses.

The forced swimming and tail suspension tests are the two widely used animal models for antidepressant screening. They are quite sensitive and specific to all the major classes of antidepressant drugs [22]. They are sensitive to both acute and chronic treatments of antidepressants [48]. The TST has a higher pharmacological sensitivity than the FST and it is also less stressful [49]. In both tests, mice are placed in an inescapable but moderately stressful situation. Lack 
of escape related behaviour is considered immobility and it reflects a state of despair which is claimed to produce in the animals a condition similar to depression in humans. This state of despair can be reduced by several agents which are therapeutically effective in human depression $[48,50]$. Reduction of the immobility time has been established to depend predominantly on the enhancement of central 5-HT and catecholamine neurotransmission [51]. In the present study, AZE failed to reduce the immobility time in the FST and TST and it therefore follows that AZE possesses no potential antidepressant activity.

Alkaloids, flavonoids, tannins, saponins, and anthraquinone glycosides were found to be present in AZE. Similarly, alkaloids, tannins, saponins, flavonoids, and cardiac glycosides in the stem bark of Albizia zygia have been reported [9]. The observed neuropharmacological effects of the plant extract could be attributed to the presence of these phytochemical constituents. However, activity-guided characterization of these groups would be needed to comprehend their role in the observed antipsychotic effects.

\section{Conclusion}

The extract of Albizia zygia produced antipsychotic-like effects in mice. It, however, did not have any antidepressant effect. These findings support the use of the plant extract in the traditional medicinal management of psychosis in Ghana.

\section{Conflicts of Interest}

The authors declare that there are no conflicts of interest regarding the publication of this paper.

\section{Acknowledgments}

The authors acknowledge the support provided by technical staff at the Animal Experimentation Unit of the NMIMR, Accra, Ghana. The research work was financially supported by the Office of Research, Innovation and Development (ORID), University of Ghana, Accra, Ghana, grant awarded to Dr. Patrick Amoateng (Reference no. URF/6/ILG002/2012-2013). The writing of the manuscript was supported by the University of Ghana, Building a New Generation of Academics in Africa (BANGA-Africa) Project with funding from the Carnegie Corporation of New York.

\section{References}

[1] M. M. Apetorgbor, "Albizia zygia (DC.) J.F.Macbr," in Record from PROTA4U, D. Louppe, A. A. OtengAmoako, and M. Brink, Eds., vol. 2015 of Plant Resources of Tropical Africa / Ressources végétales de l'Afrique tropicale, Wageningen, The Netherlands, 2007.

[2] D. K. Abbiw, Useful plants of Ghana: West African uses of wild and cultivated plants, Intermediate Technology Publications and The Royal Botanic Gardens, London, UK, 1990.

[3] U. Quattrocchi, CRC world dictionary of medicinal and poisonous plants: common names, scientific names, eponyms, synonyms, and etymology, vol. 5, CRC Press, Boca Raton, Fla, USA, 2012.
[4] I. O. Lawal, N. E. Uzokwe, A. B. I. Igboanugo et al., "Ethno medicinal information on collation and identification of some medicinal plants in Research Institutes of South-west Nigeria," African Journal of Pharmacy and Pharmacology, vol. 4, no. 1, pp. $1-7,2010$.

[5] T. Jiofack, I. Ayissi, C. Fokunang, N. Guedje, and V. Kemeuze, "Ethnobotany and phytomedicine of the upper Nyong valley forest in Cameroon," African Journal of Pharmacy and Pharmacology, vol. 3, no. 4, pp. 144-150, 2009.

[6] T. Jiofack, C. Fokunang, N. Guedje, V. Kemeuze, E. Fongnzossie, and B. Nkongmeneck, "Ethnobotanical uses of medicinal plants of two ethnoecological regions of Cameroon," International Journal of Medicine and Medical Sciences, vol. 2, no. 3, pp. 60-79, 2010.

[7] M. A. Abdalla and H. Laatsch, "Flavonoids from Sudanese Albizia zygia (Leguminosae, subfamily Mimosoideae), a plant with antimalarial potency," African journal of traditional, complementary, and alternative medicines: AJTCAM/African Networks on Ethnomedicines, vol. 9, no. 1, pp. 56-58, 2012.

[8] G. K. Oloyede and A. O. Ogunlade, "Phytochemical screening, antioxidant, antimicrobial and toxicity activities of polar and non-polar extracts of albizia zygia (DC) stem-bark," Science Domain International, vol. 3, no. 4, pp. 1-12, 2013.

[9] T. A. Abere and R. I. Jesuorobo, "Analgesic and toxicological evaluation of the stem bark of Albizia zygia Benth (Mimosoideae)," IOSR Journal of Pharmacy and Biological Sciences, vol. 9, no. 2, pp. 26-31, 2014.

[10] W. K. M. Abotsi, S. B. Lamptey, S. Afrane, E. Boakye-Gyasi, R. U. Umoh, and E. Woode, "An evaluation of the anti-inflammatory, antipyretic and analgesic effects of hydroethanol leaf extract of Albizia zygia in animal models," Pharmaceutical Biology, vol. 55, no. 1, pp. 338-348, 2017.

[11] W. K. M. Abotsi, S. B. Lamptey, E. Boakye-Gyasi, and E. Woode, "Albizia zygia (DC.) J.F. Macbr. (Leguminosae-Mimosoideae) root extract exhibits anti-nociceptive and antipyretic activities in murine models," Journal of Ethnopharmacology, vol. 199, pp. 183-193, 2017.

[12] World Health Organization, "Traditional Medicine," Fact Sheet, vol. 34, 2003.

[13] N. S. Kline, "Use of rauwolfia serpentina benth. in neuropsychiatric conditions," Annals of the New York Academy of Sciences, vol. 59, no. 1, pp. 107-132, 1954.

[14] J. M. Davis and D. L. Garver, "Neuroleptics: clinical use in psychiatry," in Handbook of psychopharmacology, vol. 10 of Neuroleptics and Schizophrenia, pp. 129-164, Springer, Berlin, Germany, 1978.

[15] D. Healy and M. Savage, "Reserpine exhumed," British Journal of Psychiatry, vol. 172, pp. 376-378, 1998.

[16] W. C. Evans, Trease and Evans' Pharmacognosy, Saunders Ltd, Edinburgh, Scotland, 15 edition, 2002.

[17] S. Irwin, "Comprehensive observational assessment: Ia. A systematic, quantitative procedure for assessing the behavioral and physiologic state of the mouse," Psychopharmacologia, vol. 13, no. 3, pp. 222-257, 1968.

[18] A. S. Davis, P. Jenner, and C. D. Marsden, "A comparison of motor behaviours in groups of rats distinguished by their climbing response to apomorphine," British Journal of Pharmacology, vol. 87, no. 1, pp. 129-137, 1986.

[19] P. R. Sanberg, M. D. Bunsey, M. Giordano, and A. B. Norman, "The catalepsy test: its ups and downs," Behavioral Neuroscience, vol. 102, no. 5, pp. 748-759, 1988. 
[20] G. Sotoing Taïwe, E. Ngo Bum, E. Talla et al., "Antipsychotic and sedative effects of the leaf extract of Crassocephalum bauchiense (Hutch.) Milne-Redh (Asteraceae) in rodents," Journal of Ethnopharmacology, vol. 143, no. 1, pp. 213-220, 2012.

[21] S. Pemminati, V. Nair, P. Dorababu, H. N. Gopalakrishna, and M. R. S. M. Pai, "Effect of ethanolic leaf extract of Ocimum sanctum on haloperidol-induced catalepsy in albino mice," Indian Journal of Pharmacology, vol. 39, no. 2, pp. 87-89, 2007.

[22] R. D. Porsolt, A. Bertin, and M. Jalfre, "Behavioral despair in mice: a primary screening test for antidepressants," Archives Internationales de Pharmacodynamie et de Thérapie, vol. 229, no. 2, pp. 327-336, 1977.

[23] D. A. Slattery and J. F. Cryan, "Using the rat forced swim test to assess antidepressant-like activity in rodents," Nature Protocols, vol. 7, no. 6, pp. 1009-1014, 2012.

[24] K. K. Kukuia, P. K. Mante, E. Woode, E. O. Ameyaw, and D. W. Adongo, "Antidepressant effects of mallotus oppositifolius in acute murine models," ISRN Pharmacology, vol. 2014, pp. 1-12, 2014.

[25] L. Steru, R. Chermat, B. Thierry, and P. Simon, "The tail suspension test: a new method for screening antidepressants in mice," Psychopharmacology, vol. 85, no. 3, pp. 367-370, 1985.

[26] B. Greenwood-Van Meerveld, A. C. Johnson, S. Cochrane, J. Schulkin, and D. A. Myers, "Corticotropin-releasing factor 1 receptor-mediated mechanisms inhibit colonic hypersensitivity in rats," Neurogastroenterology and Motility, vol. 17, no. 3, pp. 415-422, 2005.

[27] J. L. Moreno and J. González-Maeso, "Preclinical models of antipsychotic drug action," International Journal of Neuropsychopharmacology, vol. 16, no. 10, pp. 2131-2144, 2013.

[28] B. G. Katzung, S. B. Masters, and A. J. Trevor, Basic \& clinical pharmacology. edn, . Lange Medical Books/McGraw-Hill [Masters, thesis], New York, NY, USA, 2004.

[29] V. Castagné, P. Moser, and R. D. Porsolt, "Behavioral assessment of antidepressant activity in rodents".

[30] K. M. Brophy, H. Scarlett-Ferguson, K. S. Webber, A. C. Abrams, and C. B. Lammon, Clinical Drug Therapy for Canadian Practice, Wolters Kluwer Health/Lippincott Williams \& Wilkins, Philadelphia, Pa, USA, 2nd edition, 2010.

[31] H. P. Rang, J. M. Ritter, R. J. Flower, and G. Henderson, Rang Dale's Pharmacology: with student consult online access, Elsevier Health Sciences, Amsterdam, The Netherlands, 2014.

[32] D. M. Gardner, R. J. Baldessarini, and P. Waraich, "Modern antipsychotic drugs: a critical overview," Canadian Medical Association Journal, vol. 172, no. 13, pp. 1703-1711, 2005.

[33] B. K. Lipska and D. R. Weinberger, "To model a psychiatric disorder in animals: schizophrenia as a reality test," Neuropsychopharmacology, vol. 23, no. 3, pp. 223-239, 2000.

[34] V. Pandy, M. Narasingam, and Z. Mohamed, "Antipsychoticlike activity of Noni (Morinda citrifolia Linn.) in mice," $B M C$ Complementary and Alternative Medicine, vol. 12, article no. 186, 2012.

[35] P. Seeman, "Brain dopamine receptors", Pharmacological Reviews, vol. 32, no. 3, pp. 229-313, 1980.

[36] J. C. Stoof and J. W. Kebabian, "Two dopamine receptors: biochemistry, physiology and pharmacology," Life Sciences, vol. 35, no. 23, pp. 2281-2296, 1984.

[37] K. Matsumoto, B. Cai, H. Ohta, L. Imamura, and H. Watanabe, "Apparent enhancement by SCH 23390 of apomorphineinduced locomotor activity in mice," Pharmacology, Biochemistry and Behavior, vol. 39, no. 3, pp. 699-703, 1991.
[38] J. J. Battisti, N. J. Uretsky, and L. J. Wallace, "Sensitization of apomorphine-induced stereotyped behavior in mice is context dependent," Psychopharmacology, vol. 146, no. 1, pp. 42-48, 1999.

[39] K. Matsumoto, C. Bing, K. Sasaki, and H. Watanabe, "Methamphetamine- and apomorphine-induced changes in spontaneous motor activity using a new system to detect and analyze motor activity in mice," Journal of Pharmacological Methods, vol. 24, no. 2, pp. 111-119, 1990.

[40] H. Marcais, P. Protais, J. Costentin, and J. C. Schwartz, "A gradual score to evaluate the climbing behaviour elicited by apomorphine in mice," Psychopharmacology, vol. 56, no. 2, pp. 233-234, 1978.

[41] R. E. Wilcox, R. V. Smith, J. A. Anderson, and W. H. Riffee, "Apomorphine-induced stereotypic cage climbing in mice as a model for studying changes in dopamine receptor sensitivity," Pharmacology, Biochemistry and Behavior, vol. 12, no. 1, pp. 2933, 1980.

[42] S. H. Jeong, J. Y. Kim, E. Kim, and I. W. Chung, "Effects of newer antipsychotic drugs on apomorphine-induced climbing behavior in mice," Korean Journal of Psychopharmacology, vol. 16, no. 6, pp. 455-461, 2005.

[43] N. A. Moore and M. S. Axton, "Production of climbing behaviour in mice requires both $\mathrm{D} 1$ and $\mathrm{D} 2$ receptor activation," Psychopharmacology, vol. 94, no. 2, pp. 263-266, 1988.

[44] D. C. Hoffman and H. Donovan, "Catalepsy as a rodent model for detecting antipsychotic drugs with extrapyramidal side effect liability," Psychopharmacology, vol. 120, no. 2, pp. 128-133, 1995.

[45] B. Bricker, D. Sampson, and S. Y. Ablordeppey, "Evaluation of the potential of antipsychotic agents to induce catalepsy in rats: assessment of a new, commercially available, semi-automated instrument," Pharmacology Biochemistry and Behavior, vol. 120, pp. 109-116, 2014.

[46] K. Åberg, D. E. Adkins, J. Bukszár et al., "Genomewide association study of movement-related adverse antipsychotic effects," Biological Psychiatry, vol. 67, no. 3, pp. 279-282, 2010.

[47] V. Castagné, P. C. Moser, and R. D. Porsolt, "Preclinical behavioral models for predicting antipsychotic activity," Advances in pharmacology (San Diego, Calif.), vol. 57, pp. 381-418, 2009.

[48] A. Can, D. T. Dao, C. E. Terrillion, S. C. Piantadosi, S. Bhat, and T. D. Gould, "The tail suspension test," Journal of Visualized Experiments : JOVE, no. 59, Article ID e3769, 2012.

[49] B. Thierry, L. Stéru, P. Simon, and R. D. Porsolt, "The tail suspension test: ethical considerations," Psychopharmacology, vol. 90, no. 2, pp. 284-285, 1986.

[50] P. Santosh, R. Venugopl, A. S. Nilakash, S. Kunjbihari, and L. Mangala, "Antidepressant activity of methanolic extract of Passiflora foetida leaves in mice," International Journal of Pharmacy and Pharmaceutical Sciences, vol. 3, no. 1, pp. 112-115, 2011.

[51] F. Borsini and A. Meli, "Is the forced swimming test a suitable model for revealing antidepressant activity?" Psychopharmacology, vol. 94, no. 2, pp. 147-160, 1988. 


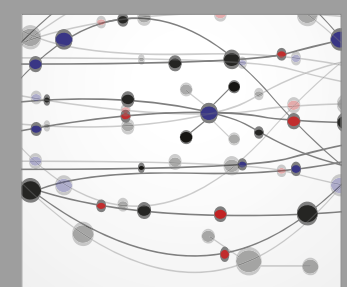

The Scientific World Journal
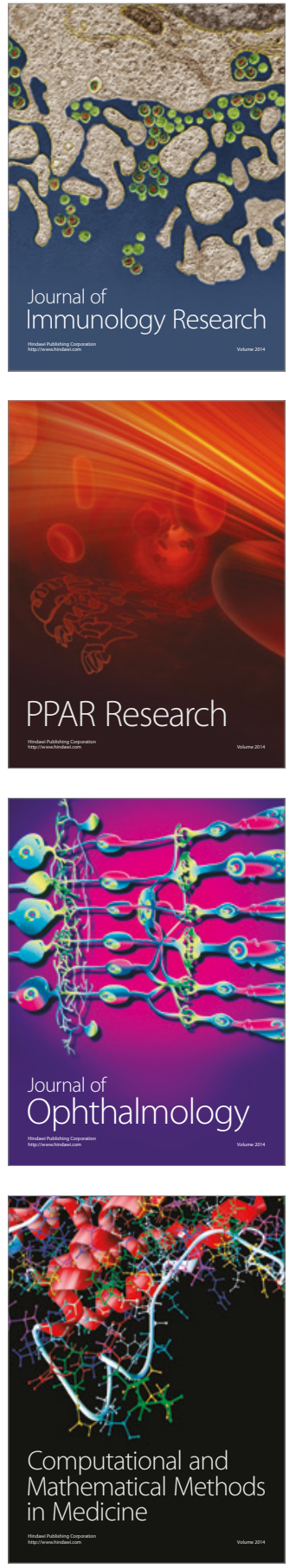

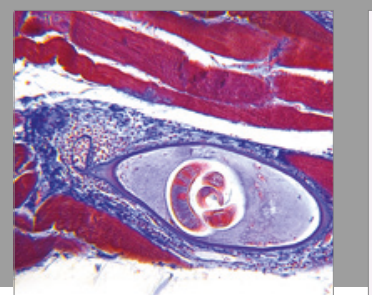

Gastroenterology Research and Practice
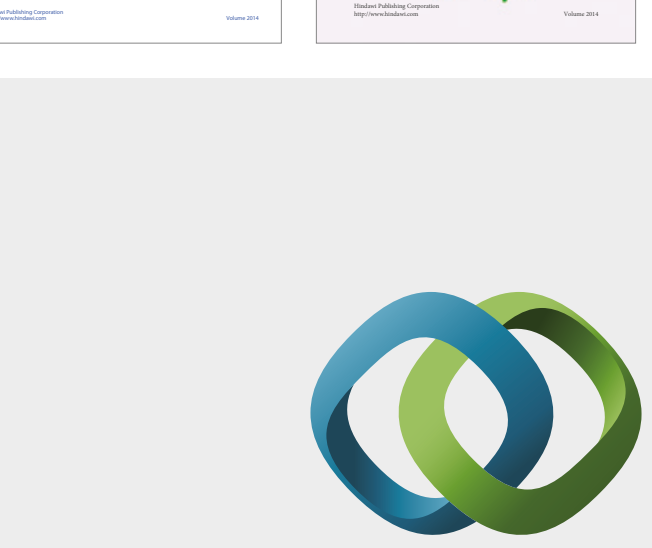

\section{Hindawi}

Submit your manuscripts at

https://www.hindawi.com
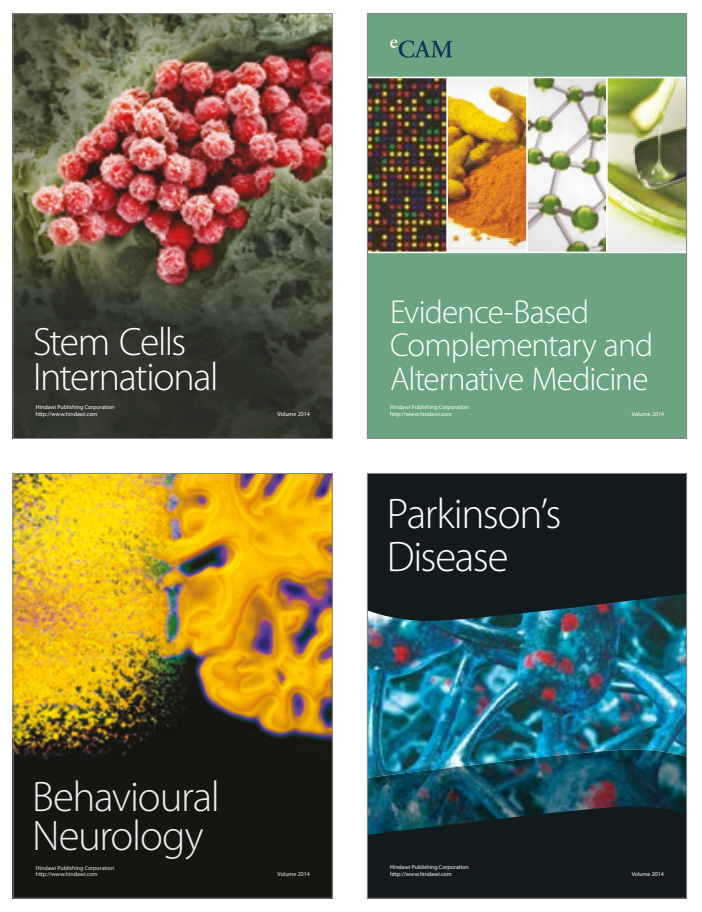
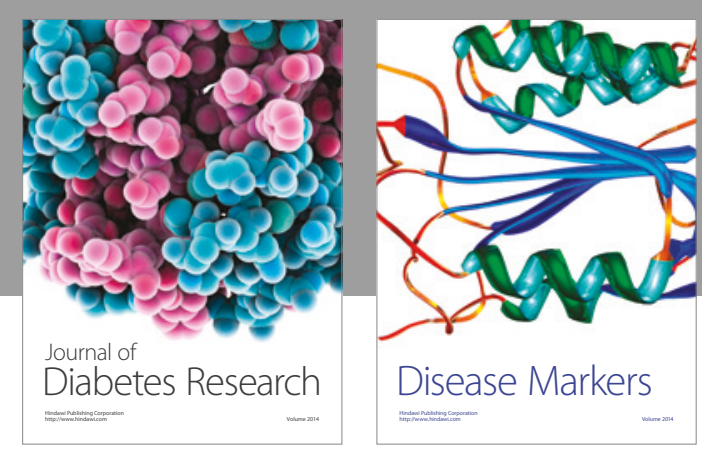

Disease Markers
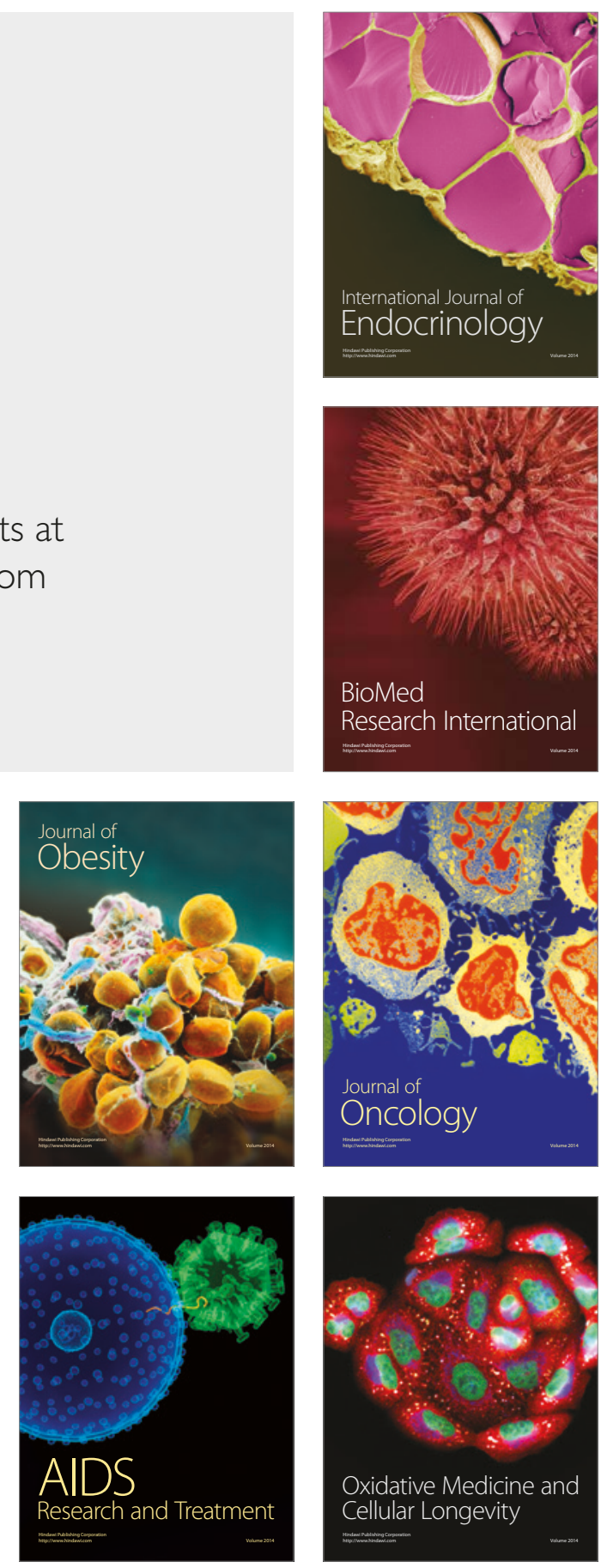